\title{
Changes in the expression pattern of epidermal stem cell markers in acute and chronic psoriatic lesions
}

Akut ve kronik psoriatik lezyonlarda epidermal kök hücre belirteç ekspresyon paternlerinin değișimi

๑ Osman Köse, ๑ Murat Demiriz*

Private Office, Ankara, Turkey

*University of Health Sciences Turkey, Gülhane Training and Research Hospital, Department of Pathology, Ankara, Turkey

\begin{abstract}
Background and Design: The characteristic morphology of skin is maintained by the self-renewal of epidermal stem cells located in the basal layer and in hair follicles in skin diseases. In this study, we tried to determine the pattern of epidermal stem cell location and how it is influenced by hyperproliferative skin disease such as acute and chronic psoriatic lesions.

Materials and Methods: Known epidermal stem cell markers such as beta 1 ( $\beta 1)$ integrin, cytokeratin 15 (CK15), Melanoma-associates chondroitin sulphate proteoglycan core protein (MCSP), transcription factor (p63) and proliferative factor Ki-67 were stained in normal skin (NS) and in acute/chronic psoriasis for comparison, using immunocytochemistry. Normal skin $(n=4)$, acute $(n=5)$ and chronic $(n=5)$ psoriasis tissue samples were immunostained with monoclonal antibodies against these epidermal stem cell markers.

Results: In this preliminary study, $\beta 1$ integrin and p63 showed strong expression in basal and suprabasal layer of the epidermis in acute psoriatic lesions while basal expressions were detected solely in chronic psoriatic lesions. Weakly positive Ki-67 positive cells in acute lesion were scattered in the basal layer. In chronic lesions, Ki-67 expression was abundant in the basal and adjacent suprabasal layer. CK15 and MCSP are not expressed in all psoriatic lesions.

Conclusion: $\beta 1$ integrin and p63 (+) interfollicular epidermal stem cells especially participate in acute phase of psoriasis while Ki-67 predominates in chronic psoriatic lesions. No role of MCSP and CK15 in pathogenesis of psoriasis has been determined.

Keywords: Epidermal stem cells, p63, MCSP, Beta-1 integrin, K15, Ki-67, psoriasis

\section{Öz}

Amaç: Derinin tipik morfolojisi, deri hastalıklarında bazal tabaka ve kıl follikülünde yer alan epidermal kök hücrelerce sağlanmaktadır. Bu çalışmada, epidermal kök hücrelerin lokasyonu saptanmaya çalısıılmış ve akut ve kronik psoriatik lezyonlar gibi hiperproliferatif deri hastalıklarından nasıl etkilendikleri araştıııımışır.

Gereç ve Yöntem: Bilinen epidermal kök hücre belirteçlerinden beta 1 ( $\beta 1$ ) integrin, sitokeratin 15 (CK15), melanom-ortakları kondroitin sülfat proteoglikan çekirdek proteini (MCSP), transkripsiyon faktörü (p63) ve proliferatif faktör Ki-67, normal ve akut/kronik psoriatik lezyonlarda immünohistokimyasal metotla boyanmışlardır. Normal deri $(n=4)$, akut $(n=5)$ ve kronik $(n=5)$ psoriatik doku örnekleri, bu epidermal kök hücre belirteçlerine karş geliştirilen monoklonal antikorlar ile boyanmışlardır.

Bulgular: Bu ön çalışmada, akut psoriatik lezyonlarda, $\beta 1$ integrin ve p63, bazal ve suprabazal tabakada kuvvetli ekspresyon gösterirken kronik lezyonlarda sadece bazal tabakada ekspresyon göstermişlerdir. Akut lezyonlarda, Ki-67 pozitif hücreler bazal tabakada dağınık ekspresyon gösterirken kronik lezyonlarda bazal ve yakın suprabazal tabakada yoğun ekspresyon gözlenmiştir. CK15 ve MCSP, akut/kronik psoriatik lezyonlarda eksprese olmamışlardır.

Sonuç: $\beta 1$ integrin and p63 (+) interfoliküler epidermal kök hücreleri özellikle akut faz psoriazisde yüksek iken, kronik psoriatik lezyonlarda Ki-67 yüksek bulunmuştur. MCSP ve CK15'in psoriazis patogenezinde herhangi bir rolü saptanamamıştır.

Anahtar Kelimeler: Epidermal kök hücreler, p63, MCSP, Beta-1 integrin, K15, Ki-67, psoriazis
\end{abstract}

Address for Correspondence/Yazıșma Adresi: Osman Köse MD, Private Office, Ankara, Turkey

Phone: +90 3122877646 E-mail: drokose@yahoo.com.tr Received/Geliş Tarihi: 22.11.2018 Accepted/Kabul Tarihi: 30.12.2019 ORCID: orcid.org/0000-0003-4070-6676

CCopyright 2020 by Turkish Society of Dermatology and Venereology

Turkderm - Turkish Archives of Dermatology and Venereology published by Galenos Yayınevi. 


\section{Introduction}

Homeostasis in continuously renewing epidermis of the skin is maintained by Epidermal Stem Cells (ESCS), which are a small population of undifferentiated, self-renewing basal keratinocytes that produce transit amplifying cells to make up for the majority of the proliferative basal cell population in the epidermis ${ }^{1-3}$. Human skin epidermis is composed of different sources of epidermal stem cells. Interfollicular epidermis (IFE), hair follicles, sebaceous glands have their own stem cell populations ${ }^{4,5}$.

Psoriasis vulgaris is a chronic immune-regulated skin disease mediated by keratinocytes and T-cells ${ }^{6,7}$. Hyperactivity of Th1, Th17, dysregulation of Treg, and the complex relationship between immune system cells and keratinocytes and vascular endothelium play significant role in pathogenesis in psoriasis. The 17 cytokines such as interleukin17A (IL-17A), IL-22 are most active in the pathogenesis in psoriasis. These cytokines activate the ESCs form a quiescent state into a hyperproliferative state ${ }^{8}$. As an epidermal stem cell marker, beta 1 $(\beta 1)$ integrin is known to play a role in keratinocytes differentiation and tissue assembly. It was shown that interfollicular epidermal stem cells (IESC) can be distinguished from other keratinocytes by the high expression of $\beta 1$ integrin and the lack of expression of terminal differentiation markers ${ }^{9-11}$. In addition to absence of these markers, expression of CK15 is restricted to cells located in the bulge region of human hair follicles in all healthy skin samples ${ }^{12,13}$. In various studies, Melanoma-associates chondroitin sulphate proteoglycan core protein (MCSP), a known epidermal stem marker, was found predominantly at the tips of the dermal papillae, where the basal layer of the epidermis is closest to the skin surface ${ }^{14,15}$. The p63, a member of the $p 53$ gene family, was identified as a transcription factor. It was shown to have a role in the maintenance of epidermal stem cells and the stratification of the epidermis ${ }^{16-18}$. In addition, Ki-67 antigen is identified as a nuclear matrix protein that is expressed in proliferating cells, but not in resting cells ${ }^{19,20}$. Therefore, Ki-67 has been used to investigate non-stem cell populations. Until now, no highly specific ESC markers, transcription factors and proliferative markers were investigated in hyperproliferative skin disease. In this preliminary study, in order to assess the expression of IESC in acute and chronic psoriatic lesions, the expression pattern of the ESC markers such as $\beta 1$-integrin, CK15, and MCSP, and also proliferative markers such as p63, and Ki-67 were analyzed using immunohistochemistry.

\section{Materials and Methods}

Tissue samples: Four samples of normal and acute $(n=5)$ and chronic $(n=5)$ psoriatic skin were collected for diagnostic purposes with the informed consent of the patients. These patients were confirmed to not have received any antipsoriatic treatment such as phototherapy or topical corticosteroids cream during the previous for one-year period. We called acute lesion which is characterised by increased erythema and decreased scaling and occurred within 10 days. On the contrary, a chronic lesion which is characterised by decreased erythema and increased scaling and developed more than 30 days. $4 \mathrm{~mm}$ punch biopsy samples of the early and late lesions were taken from the same patient. We identfied some histopathologic evidence that supports the acute or chronic period of the psoriatic lesion. In acute lesions, multiple polymorphonuclear neutrophils were prominent; while T-cells and mononuclear cells were predominate in chronic lesions. Paraffinembedded tissues were evaluated with hematoxylin and eosin staining to confirm the diagnosis. Informed consent was obtained from all individual participants included in the study. The procedure for taking human skin biopsies was approved by the Gülhane Military Medical Academy Local Ethical Committee (approval number: 2005/33).

Antibodies: The antibodies used in this study were anti-MCSP (clone LHM2, BD Biosciences, USA), anti-K15 (clone LHK15, Neomarkers, Tremont, CA, USA), anti $\beta 1$-integrin (clone P5D2, Dako Cytomation, Glastrup, Denmark), anti-p63 (63P03, Neomarkers, Tremont, CA, USA) and anti-Ki67 (N 1574, Novacastra, Newcastle upon Tyne, UK). Biotinylated rabbit anti-mouse antibody and streptavidin-biotin horseradish peroxidase were purchased from Vector Lab UK Ltd.

Immunohistochemistry: Tissue samples were mounted in cryo-m-bed on cork discs from which and $5 \mu \mathrm{m}$ sections were cut and stored at -80 ${ }^{\circ} \mathrm{C}$ until they were used. When ready to use the slides were dried at room temperature for one hour and then fixed in acetone at $4{ }^{\circ} \mathrm{C}$ for ten minutes. The sections were then incubated in ethanol (70\%) for one minute and incubated in hydrogen peroxidase (3\%) for two minutes. To reduce non-specific binding, the sections were blocked with $50 \%$ $(\mathrm{v} / \mathrm{v})$ horse serum in phosphate-buffered saline (PBSA) for 5 minutes. After washing with PBSA for two minutes, sections were incubated in a humid chamber at room temperature with primary monoclonal antibody for ninety minutes at a concentration of $10-20 \mu \mathrm{g} / \mathrm{mL}$. Then PBSA sections were treated with secondary biotinylated antibodies using the Vectastain Universal ABC Kit according to the manufacturer's instructions. Following washes with PBSA, sections were developed in a solution of $200 \mu \mathrm{g} / \mathrm{mL}$ diaminobenzidine (DAB, Sigma). Finally, sections were counterstained with hematoxylin, dehydrate with an ascending alcohol series followed by two incubations with xylene (each for two minutes) and then mounted with the xylene-based DPx mountant (Merck UK). Control experiments were performed without including primary antibodies or including SP2 conditioned medium as a negative control group. Sections were photographed with a Nikon microscope using a digital camera and the pictures were assembled using Adobe Photoshop software version 5 .

\section{Statistical Analysis}

After immunohistochemical staining for epidermal stem cell markers and Ki-67, three high power field images (HPFs, 200) were randomly selected in each field, from which an average percentage of positive cells for each of the stainings were calculated. The expression levels of epidermal stem cell markers, p63 and Ki-67 were graded semiquantitatively as negative $(-)$, weak $(+)$, moderate $(2+)$, or strong $\left(3^{+}\right)$based on the intensity and extent of staining. Ki67, positivity was additionally determined by counting stained cells in three randomly selected fields (x400); results are given as mean percentage of positive cells.

\section{Results}

Epidermal stem cell markers ( $\beta 1$-integrin, CK15 and MCSP) expressions in normal skin, acute and chronic psoriatic lesions are shown in Figure 1. $\beta 1$-integrin showed strong expression in the basal and suprabasal epidermis as well as in the dermal endothelium and capillaries in the 


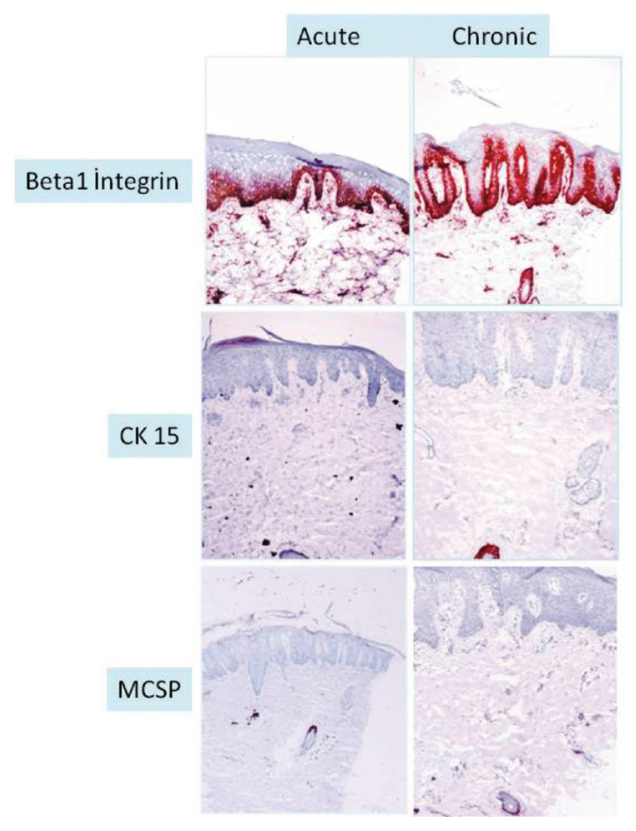

Figure 1. The expression profiles of stem cells markers [beta 1 ( $\beta 1)$ Integrin, Cytokeratin 15 (CK15), and Melanoma-associates chondroitin sulphate proteoglycan core protein (MCSP)] and were detected in acute and chronic psoriatic lesions; whereas $\beta 1$-integrin was prominent in basal and suprabasal layers in acute psoriatic lesions, in chronic lesions the weak expression was particularly confined to the basal layers. CK15 and MCSP did not show any differences in acute and chronic psoriatic lesion

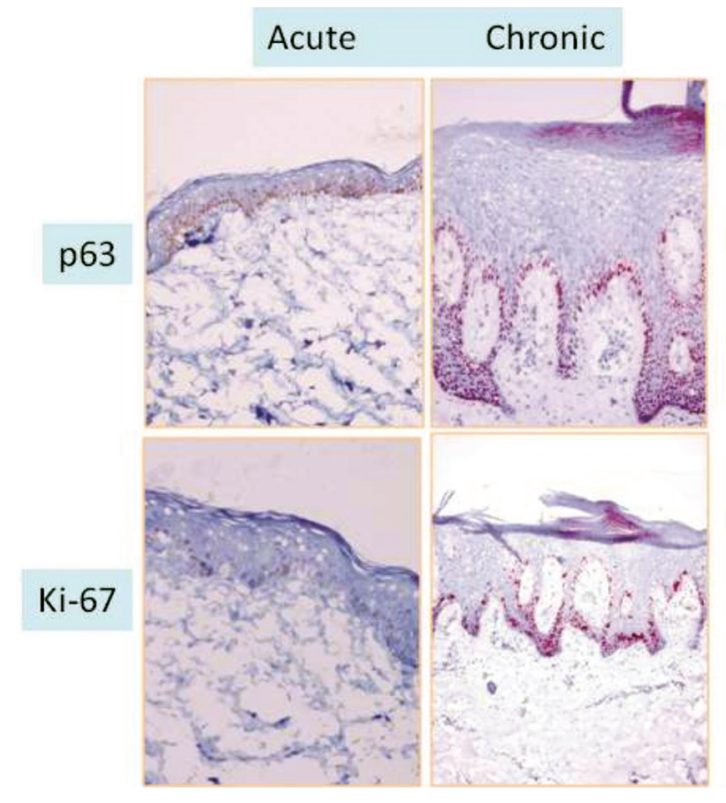

Figure 2. The expression profiles of transcription factor p63 and cellular proliferation marker (Ki-67) were detected in acute and chronic psoriatic lesions. In acute lesions, p63 were more confined to the basal and the suprabasal layer of the psoriatic epidermis while in chronic lesions p63 were localized only basal layer. Weakly positive Ki-67 positive cells in acute lesion were scattered in the basal layer. In chronic lesions, Ki-67 expression was abundant in the basal and adjacent suprabasal layer normal control skin. $\beta 1$-integrin expression was prominent in basal and suprabasal layers in acute psoriatic lesions, while the expression was particularly confined to the basal layers in chronic lesions.

CK15 and MCSP are normally expressed in the bulge area of the hair follicle in the normal control skin. In the present study, CK15 and MCSP were expressed on the outer sheath of hair follicle but were absent in the IFE in psoriatic samples.

p63 and Ki-67 expression are shown in Figure 2. p63 is expressed in the basal cell layer and in a few lower cell layers of the suprabasal epidermis in the normal control skin. p63 is downregulated in terminally differentiated cells. In acute psoriasis, p63 is expressed in the basal cell and lower cell layers of the acanthotic epidermis while in chronic psoriasis, p63 positive cells were localized only to the basal cell layer and a few spinous cell layers. Also, p63 staining was more prominent in the smaller nuclei of the cell that localized in the protruding edges of the rete ridges.

Ki-67 was sparse in the basal layer and next upper layer normal control skin. Weakly positive Ki-67 positive cells in acute lesions were scattered in the basal layer. In chronic lesions, Ki-67 expression was abundant in the basal and adjacent suprabasal layer. Staining intensity and expression pattern of the all stem cells, transcription and proliferative markers in the acute and chronic phase psoriasis was shown in Table 1.

Table 1. Expression pattern and degree of the epidermal stem cell markers in the acute and chronic psoriatic epidermis

\begin{tabular}{|l|l|l|l|l|l|}
\hline & CK15 & MCSP & $\boldsymbol{\beta 1}$ integrin & P63 & Ki-67 \\
\hline $\begin{array}{l}\text { Acute } \\
\text { lesions }\end{array}$ & - & - & $\begin{array}{l}\text { B (+++) } \\
\text { SB (++) }\end{array}$ & $\begin{array}{l}\text { B (++) } \\
\text { SB (++) }\end{array}$ & B (+) \\
\hline $\begin{array}{l}\text { Chronic } \\
\text { lesions }\end{array}$ & - & - & $\begin{array}{l}\text { B (++) } \\
\text { SB (+) }\end{array}$ & $\begin{array}{l}\text { B (+) } \\
\text { SB (+) }\end{array}$ & $\begin{array}{l}\text { B (++) } \\
\text { SB (++) }\end{array}$ \\
\hline $\begin{array}{l}\text { Normal } \\
\text { control }\end{array}$ & Bulge (+++) & DP (++) & $\begin{array}{l}\text { B (+) } \\
\text { SB (++) }\end{array}$ & B (+) & B (+) \\
\hline $\begin{array}{l}\text { Staining intensity was scored by eye as negative (-/+), weak (+), moderate (++), or } \\
\text { strong (+++), based on the intensity and extent of staining } \\
\text { CK15: Cytokeratin 15, MCSP: Melanoma-associates chondroitin sulphate } \\
\text { proteoglycan core protein, B: Basal, SB: Suprabasal, DP: Dermal Papilla }\end{array}$ \\
\hline
\end{tabular}

\section{Discussion}

Psoriasis is a chronic, inflammatory, papulosquamous skin disease. Keratinocytes-T lymphocytes interaction play a major role in the pathogenesis of psoriasis. But it is not easy to explain psoriasis solely on the basis of T-cell activation. It can be speculated that intrinsic alterations in epidermal keratinocytes play an important role in the pathogenesis of psoriasis. Particularly, basal keratinocytes are assumed to initiate main inflammatory responses.

Homeostasis of the skin is still poorly understood and assumed to be mainly related to the functions of the IESC. Unipotent IESC and their progenitors are essential for maintaining for IFE therefore basal layer is not only a mitotically active layer but also the IFE have its own stem cell population in the $\mathrm{skin}^{21}$. Proliferation and differentiation of keratinocytes are accompanied by differences in the expression of epidermal stem cell markers. The basal layer of the epidermis composes 
of two distinct keratinocytes; IESCs and transit-amplifying (TA) cells. Increased turn over time indicates that more IESC cells enter into the cell cycle in psoriasis. Basal keratinocytes which are strongly positive for $\beta 1$ integrin are indicative of epidermal stem cells, whereas cells expressing low levels of $\beta 1$ integrin are transient-amplifying cells, and $\beta 1$ integrin-negative cells are post-mitotic, differentiating these cells ${ }^{22}$. Previous studies indicated that, IESC possess a high level of $\beta 1$ integrins. The increase of $\beta 1$ integrin positive cells is believed to represent the proliferation of TA cells. Activated IESC gives rise to the extreme expansion of TA cells in the psoriatic epidermis ${ }^{23}$.

$\beta 1$ integrin is downregulated when keratinocytes initiate terminal differentiation, thereby indicating that downregulation of $\beta 1$ integrin occurs in hyperproliferative diseases ${ }^{10,24}$. In addition, the suprabasal expression of $\beta 1$ integrin might be related to the hyperproliferative state of keratinocytes. Mediate keratinocyte adhesion to extracellular matrix component $\beta 1$-integrin shows strong expression in the basal and suprabasal epidermis as well as in the dermal endothelium and capillaries in normal skin ${ }^{11,25}$. It is claimed that $\beta 1$-integrin expression on basal keratinocytes is a key determinant which controls the migration of the keratinocytes from the basal layer to the suprabasal layer ${ }^{24,25}$. In the present study, whereas $\beta 1$-integrin expression was prominent in basal and suprabasal layers in acute lesions, the weak expression was particularly confined to the basal layers in the chronic phase. IESC expresses higher levels of $\beta 1$-integrin than TA cells. TA cells not expressing $\beta 1$-integrin leave the basal layer of the epidermis and enter the suprabasal layer. This implies that hyperproliferation of the epidermis is caused by an increase in the number of TA cells ${ }^{25}$.

CK15 downregulated should be due to immunological activation of the keratinocytes in psoriasis. And also, the identification of MCSP in the basal layer of the epidermis, more undifferentiated keratinocytes and the loss of expression of differentiation would be compatible with a role for this molecule in controlling cell growth and differentiation in keratinocytes ${ }^{12,15}$. We have found that CK15 and MCSP localized on the outer sheath of the hair follicles and perivascular area. This means that CK15 and MCSP could not participate of in the pathogenesis of the acute and chronic phase psoriasis in this study.

On the other hand, p63 has a prominent role on over epidermal differentiation. p63 is a nuclear transcription factor that triggers keratinocytes differentiation and is downregulated in terminally differentiated cells. p63 is the most promising gene product which is capable of distinguishing stem cells from their transient amplifying progeny ${ }^{16-18}$. p63 could play a role in the maintenance of ESCs. It was found that p63 positivity in the basal layer and in 2 to 4 layers of the spinous cell layer. Also, it was shown that as the elongated epidermis, p63-positive cells moved down and were localized in the lower parts of the rete ridges where keratinocytes densely proliferated ${ }^{16}$. Expression of p63 was examined in hyperproliferative condition, including psoriasis by Kim et al. ${ }^{18}$ That study suggests that molecular differentiation control of p63 is severely disorganized in hyperproliferative disease. In our study, p63 was found to be downregulated in terminally differentiated cells. p63 was expressed in the basal cell and lower cell layers of the acanthotic epidermis in the acute phase of psoriasis while in chronic phase, p63 positive cells were localized only to the basal cell layer and a few elongated spinous cell layers ${ }^{18}$.

As a proliferation markers, Ki-67, is associated with increased epidermal turnover rate and mitotic index. Proliferative keratinocytes, as demonstrated by Ki-67 staining, were scattered in the basal and suprabasal cell layers of the normal epidermis ${ }^{19}$. It was found that the percentage of Ki-67 positive cells in the basal layer of normal and psoriatic skin were 4.5 and $54 \%$ respectively ${ }^{20}$. In the present study, weakly positive $\mathrm{Ki}-67$ positive cells in the acute lesion were scattered in the basal layer. In chronic lesions, Ki-67 expression was abundant in the basal and adjacent suprabasal layer.

\section{Study Limitation}

There were some limitations in this preliminary study. Main limitation was number of samples. Second limitation was the restriction of using the different epidermal stem cells markers. Some epidermal stem cell markers may shed light upon the relationship between basal and differentiated keratinocytes in psoriasis.

\section{Conclusion}

Taken together, these datum provide that, in the acute psoriatic skin samples, IESC expresses dense $\beta 1$ integrin and p63 than TA cells, whereas TA cells have a downregulated expression of $\beta 1$ integrin and p63. $\beta 1$ integrin and p63 expression levels are a key determinant which control the keratinocytes from the basal layer to the suprabasal layers. It can be speculated that IESC has a role in the acute phase of psoriasis. $\beta 1$ integrin and p63 deficient cells exit the stratum basale and enter the suprabasal layer, and keratinization are occurs spontaneously. Further experiments are required to fully characterize and determine IESCS role in keratinocyte biology in normal skin and hyperproliferative skin conditions. Inhibition of the hyperactivity of the IESCs could bring a potential therapeutic option to combat epidermal hyperplasia in psoriatic skin lesions.

Acknowledgments: The authors would like to thank "Ahmad Waseem PhD" for the support of monoclonal antibodies and also wish to thank "Cenk Öner" his assistance with the correction of this manuscript.

\section{Ethics}

Ethics Committee Approval: The procedure for taking human skin biopsies was approved by the Gülhane Military Medical Academy Local Ethical Committee (approval number: 2005/33).

Informed Consent: Informed consent was obtained from all individual participants included in the study.

Peer-review: Externally and internally peer-reviewed.

\section{Authorship Contributions}

Concept: O.K., M.D., Design: O.K., M.D., Data Collection or Processing: O.K., M.D., Analysis or Interpretation: O.K., Literature Search: O.K., Writing: O.K.

Conflict of Interest: No conflict of interest was declared by the authors.

Financial Disclosure: The authors declared that this study received no financial support.

\section{References}

1. Brouard M, Barrandon Y: Controlling skin morphogenesis: hope and despair. Curr Opin Biotech 2003;14:520-25.

2. Larcher F, Espada J, Diaz-Ley B. Jaén P, Juarranz A, Quintanilla M: New experimental models of skin homeostasis and diseases. Actas Dermosifiliogr 2015;106:17-28. 
3. Mascre G, Dekoninck S, Drogat B, et al: Distinct contribution of stem cells to epidermal maintenance. Nature 2012;13:489:257-62.

4. Köse O. Epidermal stem cell. Turk J Dermatol 2015;1:23-7.

5. Li Y, Zhang J, Yue J, Gou X, Wu X: Epidermal stem cells in skin wound healing. Adv Wound Care 2017;6:297-307.

6. Hawkes JE, Chan TC, Krueger JG: Psoriasis pathogenesis and the development of novel targeted immune therapies. J Allergy Clin Immunol 2017;140:645-53.

7. Hou R, Li J, Niu X, et al: Stem cells in Psoriasis. J Dermatol Sci 2016;86:181-6.

8. Nograles KE, Zaba LC, Guttman-Yassky, et al. Th 17 cytokines interleukin (IL) -17 and IL-22 modulate distinct inflammatory and keratinocyte-response pathways. Br J Dermatol 2008;159(5):1092-102.

9. Jia HY, Shi Y, Luo LF, et al: Asymmetric stem-cell division ensures sustained keratinocyte hyperproliferation in psoriatic skin lesions. Int J Mol Med 2016;37:359-68.

10. Jones PH, Watt FM: Separation of human epidermal stem cells from transit amplifying cells on the basis of differences in integrin function and expression. Cell 1993;73:713-24.

11. Van Rossum MM, Franssen MEJ, Cloin WAH, et al: Functional characterization of 1 integrin-positive epidermal cell populations. Acta Derm Venereol 2004;84:265-70.

12. Waseem A, Doğan B, Tidman N, et al: Keratin 15 expression in stratified epithelia: downregulation inactivated keratinocytes. J Invest Dermatol 1999;112:362-9.

13. Bose A, Teh MT, Mackenzie IC Wasem A: Keratin K15 as a biomarker of epidermal stem cells. Int J Mol Sci 2013;14:19385-98.

14. Ghali L, Wong ST, Tidman N, Quinn A, Philpott MP, Leigh IM. Epidermal and hair follicle progenitor cells express melanoma-associated chondroitin sulphate proteoglycan care protein. J Invest Dermatol 2004;122:433-42.

15. Legg J, Jensen UB, Broad S, Leigh I, Watt FM: Role of melanoma chondroitin sulphate proteoglycan in patterning stem cells in human interfollicular epidermis. Development 2003;130:6049-63.

16. Han SS, Chang SE, Jung HJ, Choi JH: Expression of p63 in various hyperproliferative skin diseases. Ann Dermatol (Seoul) 2006;18:64.

17. Shen CS, Tsuda T, Fushiki S. Mizutani H, Yamanishi K: The expression of p63 during epidermal remodeling in psoriasis. J Dermatol 2005;32:236-42.

18. Kim SY, Cho HJ, Kim DS, et al: Differential expression of p63 isoforms in normal skin and hyperproliferative conditions. J Cutan Pathol 2009;36:825 30.

19. Ando M, Kawashima T, Kobayashi H, Okhawara A: Immunohistological detection of proliferating cells in normal and psoriatic epidermis using Ki-67 monoclonal antibody. J Dermatol Sci 1990;1:441-6.

20. Chang SL, Hu S, Hung SI, Huang YL, Hsiao WC, Chung WH: A comparison of $\mathrm{Ki}-67$ antigen presentation in acute generalized exanthematous pustulosis and pustular psoriasis. Arch Dermatol Res 2010;302:525-9.

21. Kretzschmar K, Watt FM: Markers of epidermal stem cell subpupulations in adult mammalian skin. Cold Spring Harbor Perspect Med 2014;4:a013631.

22. Staunstrup NH, Stenderup K, MortensenS, et al: Psoriasiform skin disease in transgenic pigs with high-copy ectopic expression of human integrins $\alpha 2$ and $\beta 1$. Disease Models \& Mechanisms 2017;10:869-80.

23. Hertle MD, Kubler M-D, Leigh IM, Watt FM: Aberrant integrin expression during epidermal wound healing and in psoriatic epidermis. J Clin Invest 1992;89:892-1901

24. Conrad C, Boyman O, Tonel G, et al: $\alpha 1 \beta 1$ integrin is crucial for accumulation of epidermal $\mathrm{T}$ cells and the development of psoriasis. Nature Med 2007; 13:836-42.

25. Owczarczyk-Saczonek A, Krajewska-Wlodarczyk M, Kruszewska A, Placek W, Maksymowicz W, Wojtkiewicz J: Stem cells as potential candidate for psoriasis cell-replacement therapy. Int J Mol Sci 2017;18:2182. 